\title{
Some Aspects of the Theory of Abstraction in Plotinus and Iamblichus
}

\author{
Claudia Maggi \\ Independent Scholar \\ unotutto@yahoo.it
}

\begin{abstract}
The purpose of this paper is the analysis of the Plotinian and Iamblichean reading of the Aristotelian theory of abstraction, and its relationship with the status of mathematical entities, as they were conceived within a Platonic model, according to which mathematical objects are ontological autonomous and separate.
\end{abstract}

\section{Keywords}

Abstraction - Reduction - Ideal Numbers - Intermediates - Intelligible Matter

\section{Introduction. Separation and Abstraction as Responses to the Question of the Status of Mathematical Objects}

My purpose is the analysis of the Plotinian and Iamblichean reading of the Aristotelian theory of abstraction, and its relationship with the status of mathematical entities.

Since both Plato and Aristotle avoid any identification between objects of perception for themselves and mathematical entities, they should give an answer to the problem concerning whether and how numbers and geometrical

* I discussed this paper at the Institut für Philosophie-Universität Bonn. I am grateful to Christoph Horn and to his students for their suggestions. I also owe a special thanks to John Finamore, Anna Schriefl, Mario Coppola, Fabio Seller, and Daniela Taormina.

(C) MAGGI, 2015 | DOI 10.1163/18725473-12341314

This is an open-access article distributed under the terms of the Creative Commons AttributionNonCommercial 3.0. Unported (CC BY-NC 3.0) License, http://creativecommons.org/licenses/by-nc/3.0/ 
figures exist. The question as to whether mathematical objects are ontologically separate is answered by Plato as follows:

Would you assert that, when one is added to another one, the addition causes the creation of two, or is it caused by division, in case one was split? Wouldn't you shout (...) that you do not have any other reason for the creation of two, if not its participation in the dyad (...), and that what will be one will be in the monad? ${ }^{1}$

So he situates them in the intelligible realm. Aristotle maintains that sensible beings cannot be regarded as objects of science for themselves, but, once the ontological autonomy of ideas has been rejected, he is obliged to offer a different solution to the status of numbers and figures.

In his doxographic acknowledgement of mathematical ontology, Aristotle attributes to Plato a model, some aspects of which he would have borrowed from the Pythagoreans:

The so-called Pythagoreans (...) believed that the principles of mathematics were peculiar to all the things which exist. And since, in mathematics, numbers come first in a natural way, and since they saw in them, rather than in fire, earth or water, many features similar to the things which are and those liable to coming-to-be, they inferred that (...) the elements of numbers were elements of all the things which exist. ${ }^{2}$

Like Pythagoras, Plato seems to maintain that numbers conceived as forms are causes of every being. ${ }^{3}$ But, unlike the Pythagoreans, he would concede that numbers are transcendent. We should admit that Plato's dialogues do not offer conclusive evidence for such a model $;{ }^{4}$ nonetheless, as Gerald Bechtle claims, it may be possible to find in them some hints of intra-academic debates which could represent the reference point for the Aristotelian account. ${ }^{5}$

I will not discuss all these issues in detail. Here, I will focus on some aspects relating to the Aristotelian criticism of the separation of mathematical entities and its relationship with the doctrine of abstraction, provided by Aristotle as an attempt to reply to the Platonic model of the ontological autonomy of

1 PLAT. phaed. 101 в 9-C 7.

2 Aristot. metaph. 985 b 23 ff. See B. Centrone (2009).

3 Aristoт. metaph. 987 b 18-22. See Th. A. Szlezák (2008) 98-112.

4 In such a direction see, for example, F. F. Repellini (2003) 367.

5 See G. Bechtle (2011) 37 ff.; Th. A. Szlezák (2011) 79 ff. 
both ideas and numbers, in which the status of numbers seems to be particularly aporetic.

First of all, how can a number be ideal? If number were an idea, it should be simple and indivisible, on the one hand; but, on the other hand, numbers, in order to make calculus possible, should be as well the product of a sum of units, which could be subtracted as well as added: but, in such a way, a number will not be an idea. We should admit like a Platonist that the ideal number is not per se identical with numbers involved in the notion of calculus; moreover, calculus should not depend on the sensible per se, since sensible objects are heterogeneous, while numbers seem to be homogeneous entities. This is probably why Aristotle attributes to Plato an ontological tripartition - according to which "next to sensible entities and Forms, there are the mathematical entities, an intermediate stage between the two other realms: they differ from sensible entities since they are eternal and motionless, but they are also different from Forms since there are many similar kinds of them, whereas Forms are indivisible"; 6 moreover, he asserts that Plato would make a distinction between two kinds of numbers, the ideal one, which is not subject to calculus, and the arithmetical one, both of them separate from sensible beings. ${ }^{7}$

Now, if something is an $\mathrm{x}$-nature with respect to the X-idea and the arithmetical number should partake of the ideal one in order to be a number, one may wonder how the former can be a sum of units by addition and subtraction, without attributing the same structure to the ideal one. If, on the contrary, the ideal number is completely different and separate from what makes a number just the number linked to calculus, how can one say that the arithmetical number is actually a number without participating in the idea which alone should account for its being a number? But, if, on the other hand, the arithmetical number is a number in such a sense for itself, why should one postulate an ideal number?

The Aristotelian response to these aporias is that the status of numbers and, more broadly, of mathematical entities cannot depend on such models. Aristotle criticizes both the Pythagorean and the Platonic conceptions. ${ }^{8}$

6 Aristot. metaph. 987 b 14-18. See also metaph. 1028 b 20. For the attribution to Plato of this model see Aristot. metaph. 987 b 12.

7 See Aristot. metaph. 108 o b 11-14 and my discussion in C. Maggi (2012) 75-77. We should remind that it is not clear whether Aristotle attributes to Plato the idea that numbers come ontologically first also in respect to the other forms or only claims that he regards number as an idea besides the others. See C. Maggi (2009) 37-38 and cross references.

8 Some Academic models were probably borrowed from the Pythagorean theory of immanence. See E. Cattanei (1996) 100-102; 161-162. 
The former asserts that mathematical natures are immanent in perceptible bodies; the latter postulates the transcendence of numbers and geometrical shapes. In the Pythagorean theory a contradiction between the notions of divisibility and ontological autonomy can be found: if mathematical entities are embodied in sensible natures but are, at the same time, distinguished from them, one would be able to decompose the bodies into their indivisible mathematical elements. However, if a divisible being has an indivisible element in itself, we should admit that not even the sensible body is divisible. We must therefore reject this hypothesis. ${ }^{9}$

According to the Academic model of reduction, everything, whose disappearance would determine the elimination of something else, must come ontologically first and exist separately:

The body is surely less of a substance than the surface, and the surface than the line, and the line than the unit and the point. For the body is bounded by these; and they are thought to be capable of existing without body, but body incapable of existing without these. ${ }^{10}$

This model (the so-called dimensional-model) states that what is simple is the principle of any non-simple being: geometrical entities are the principles of perceptible bodies; moreover, since every geometrical entity is based upon an arithmetical one, it follows that numbers are the principles of everything that exists. ${ }^{11}$

This framework is rejected by the regressus argument. If mathematical entities exist as separate, one should postulate an ideal object for each geometrical entity (point-line-surface-solid). Now, since the dimensional model claims that every geometrical body finds its own 'reason' in a simpler one, we are left with two (or more) paradigms, one corresponding to the compounded body, the other to its elements. If a three-dimensional solid is the ideal paradigm of the sensible one, it will be composed of point, line and surface, each of them ideal. But, since the sensible surface partakes of an ideal one, the ideal surface will be composed of line and point, again each of them ideal. Moreover, since every geometrical entity corresponds to an arithmetical one, there will be a multiplication of eidetic entities such that they will outnumber the sensible bodies themselves:

9 See Aristot. metaph. 1076 b 4-11 and J. J. Cleary (1995) 281-284.

10 ARistot. metaph. 1002 a 4-8 (Ross' transl.). See also 1018 b 37-1019 a 4; 1076 b 18-20; ALEX. APHROD. in metaph. 55, 20-56, 1; IAMB B. in nic. 3, 5-10; comm. math. sc. 14, 1-6.

11 See Aristot. metaph. 987 b 18-988 a 1; Alex. APHrod. in metaph. 55, 20-56, 5 and E. Berti (1997) 208-209; 249-250. 
It is not possible that such entities should exist separately. For if besides the sensible solids there are to be other solids which are separate from them and prior to the sensible solids, it is plain that besides the planes also there must be other and separate planes and points and lines (...). But if these exist, again besides the planes and lines and points of the mathematical solid there must be others which are separate (...). Now, the accumulation becomes absurd. ${ }^{12}$

The so-called third man argument states, in conclusion, that there is no point in making multiple the single sensible body, by hypostatising its properties and calling them ideas. ${ }^{13}$

In replying to these aporias, Aristotle solves the issue of the constitution of mathematical entities by considering them, so to speak, as which remains in the sensible subject - that only exists per se-once what is incidental to the object of a specific branch of mathematics has been left out. Thus the abstraction can be regarded as an act of ignoring or disregarding matter and change from perceptible objects in order to leave their specifically 'mathematical' features as distinct objects of our thought, ${ }^{14}$ which allows the truth of science, without admitting the existence of ideal objects qua separate: ${ }^{15}$

Attributes do not exist apart from their substances (...). The objects of mathematics are not substances in a higher degree than bodies are, and (...) they are not prior to sensibles in being, but only in definition, and $(. .$.$) they cannot exist somewhere apart. (...) It is possible that$ there should (...) be propositions and demonstrations about sensible magnitudes, not however qua sensible but qua possessed of certain definite qualities. ${ }^{16}$

Therefore, we may conclude that mathematical entities only enjoy the property of existence en allöi, but not that kath'hauta. ${ }^{17}$

Something different would happen in the Aristotelian tradition, probably because of the influence of the Stoics. Alexander of Aphrodisias, for example, identified at some stage abstraction with the notion of $\dot{\varepsilon} \pi i^{2}(\alpha$, thus creating

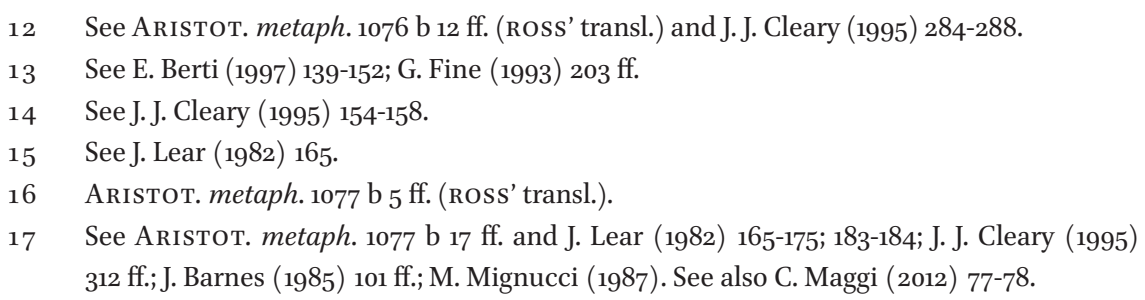


the condition to think of mathematical entities as existing only in our thought. ${ }^{18}$ Something similar to Alexander's thesis, even though in a different metaphysical context, can be found in Plotinus.

\section{Plotinus, and the Platonic Refusing of Aristotle's Abstraction}

The Plotinian treatise On numbers (vi 6 [34]) shows both the relationship between numbers and the second hypostasis, and the link between numbers and the so-called degrees of reality.

Following Plato's Phaedo and Republic, Plotinus speaks of numbers as if they were ideal and separate from the sensible realm and from the soul itself: ${ }^{9}$

In the intelligible, just as the real beings are limited so is the number limited to as many as the real beings. But we, just as we make "man" many $(. .$.$) , so along with each image we generate an image ( \varepsilon$ i $\delta \omega \lambda \circ \nu)$ of number. ${ }^{20}$

Plato says that men came to the idea of number by the alternation of day and night (...); perhaps he is saying that (...) number (...) is coming into existence (...) when the soul numbers (...). But then when Plato says "in the true number" (...) he will, on the other hand, be saying that number has an existence from itself and does not have its existence in the numbering soul. ${ }^{21}$

However, we do not find in this treatise any interest in the constitution of arithmetical numbers or in their ontological status. ${ }^{22}$ Its concern is rather to defend the eidetic status of multiplicity - since the second hypostasis consists somehow of a multiple nature-and its dependence on the One, so that Intellect is conceived as an unified $\pi \lambda \hat{\eta} \theta 0 \varsigma$. The Plotinian number thus represents the eidetic paradigm of every unified multiplicity: in such a direction Plotinus likely borrows from Aristotle the definition of number: it is a multiplicity that

18 See Alex. APhrod. in metaph. 52, 15-19; 199, 19-20; 200, 38-201, 11; Procl. in Eucl. 89, 15-22; 91, 19-24; 395, 13-18; J. J. Cleary (1995) 260-262; I. Mueller (1990) 464-468 and note 9; 474478; E. Cattanei (2003) 255-276; D. G. Robertson (2004); K. L. Flannery (2003).

19 Seе plot. Vi 6, 4-5.

20 PLOt. vi 6, 2, 9-13 (ARmstrong's transl.).

21 PLOt. vi 6, 4, 11 ff. (Armstrong's transl.). See PLAt. tim. 39 в 6-C 1; 47 A 4-6; resp. vil 529 D 2-3; epin. 978 D $1 \mathrm{ff}$.

22 See C. Maggi (2009) 17-20. 
has certain limits ${ }^{23}$ - limits that, according to Plotinus, would be made possible by virtue of the One. ${ }^{24}$

Plotinus' theory of numbers and his reading of the Platonic/Academic doctrines must therefore be related to his model of derivation: since Plotinus does not consider any multiplicity as completely opposed to the One, numbers indicate, on the one hand, the separation of the One from the Intellect-which is multiple in that it is different from the One itself even though, at the same time, must retain a trace of resemblance to the One for its dependence on it - and, on the other, the idea that the intelligible $\pi \lambda \hat{\eta} \theta 0 \varsigma$ has to receive the unification of its intrinsic multiplicity by turning to the One, which is necessary if it is to come into being as a determined nature. ${ }^{25}$

In such a direction the principle of reduction is borrowed from the Old Academy, since, if the paradigm of multiplicity did not exist, neither multiplicity could exist. When Plotinus resorts to the idea of the priority of numbers even over forms, this conclusion has thus to be connected to the consideration that numbers are the first image of the One in the sphere of being and the ontological predetermination for the multiplicity that comes into being:

In general $(. .$.$) it must be accepted that everything (. .$.$) which is predi-$ cated of something else came to it from something else or is the active actuality of the thing of which it is predicated. (...) And if that thing could be thought of without its actual activity, that activity could none the less be simultaneous to it, but ranked later by us in our thought. But if it cannot be thought except along with what is predicated of it (...) it is either not posterior to but co-existent with it, or prior to it, so that the

23 See Aristot. metaph. 1020 a 13.

24 Numbers, in other words, become the paradigmatic natures thanks to which the intelligible multiplicity comes into being through the separation from the absolute simplicity of the first principle. See C. Maggi (2009) 6o-61.

25 See PLOT. V 1, 5, 6-9. Seeking support in the Sophist, where Plato acknowledges multiplicity as an intrinsic feature of the intelligible Being, Plotinus characterises his second hypostasis with the connotation of multiplicity and interprets Plato's dialogues in order to equate "number with substance, power, and activity of being" (S. Slaveva-Griffin (2009) 87). However, when he defends the dependence of the Multiple on the One, he looks at the Old Academic doctrines regarding the production of numbers from the One and the Indefinite Dyad, but the latter is no longer conceived as a second principle that causes numbers and forms together with the One. See PLOT. VI 6, 7-9; 17-18; V 4, 2, 4-10 and M. Ninci (2000) 392-394 notes 18-20; M. Ninci (2001) 463; 468-470; 473-474; S. SlavevaGriffin (2009) 68-70. 
thing may exist through the activity; but we maintain that the one and number are prior. $^{26}$

Here we have, in a genuine Platonic spirit, the identification between priority in definition as well as in existence, according to which Plotinus is conceiving of numbers as universal predicates, whose existence is thus the condition for the existence of the things of which they are predicated.

Once the Number has been put at the ontological level of Being, it follows that everything is to participate in it in order to exist. Moreover, since the Platonic participatory model is transformed by Plotinus into a monopolar framework according to which everything in the sensible world must be reduced to its eidetic causes, any aspect of the sensible world can avoid participation in ideal numbers: ${ }^{27}$

These are the first numbers ( $\pi \rho \omega \hat{\tau} \tau$ or $\dot{\alpha} \rho(\theta \mu o i)$, as numbered; but those

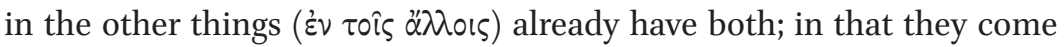
from these first ( $\pi \alpha \rho \dot{\alpha} \tau o v ่ \tau \omega \nu)$, they are numbered numbers, but in that they are according to these, they measure the other things, numbering both the numbers and the things numbered. ${ }^{28}$

The "first numbers" are the eidetic numbers in themselves. How can these numbers escape the Aristotelian aporias about arithmetical entities? The answer lies in the Plotinian doctrine of vertical causality, according to which what comes ontologically first produces what follows, without sharing its nature. ${ }^{29}$ It follows that the ideal numbers are devoid of arithmetical features in the 'Aristotelian' sense - they are simple and indivisible as forms-even though they are numbers.

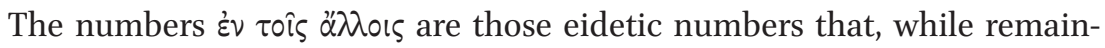
ing in themselves, are present both in every existing thing which participates in them-the ideal causes, since they are bodiless, can in fact be present

26 PLOT. Vi 6, 10, 39-51 (ARMStrong's transl.).

27 For the role of the eidetic beings as causes see M. Ninci (2010); R. Chiaradonna (2010); P. Kalligas (2011).

28 PLOT. vi 6, 15, 37-41 (ARMStrong's transl.).

29 For the theme of vertical causality in Plotinus see discussion and bibliographic references in C. Maggi (2009) 29-31; C. Maggi (2010) 81 ff.; 123-125. 
everywhere without being anywhere ${ }^{30}$ —and in the soul itself, when it counts/ discovers the eidetic roots in the sensible realm. ${ }^{31}$

When Plotinus, moreover, distinguishes the essential number per se from the act of counting by the individual soul, he introduces a distinction between a substantial act, by which the soul recognizes the dependence of sensible beings on the eidetic ones, and a 'quantitative' act, which does not relate itself directly to the higher-lower structured sensible beings but, instead, looks at sensible beings externally and, so to speak, from below, as they existed as utterly separate from the ideal realm:

When $(\ldots)$ you take one thing after another and say "two" (...), this number is not a substance, not even the kind of substance which occurs

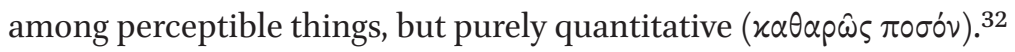

It is thanks to the abstraction/separation of the sensible not only from the eidetic/qualitative causes, but also from the substantial features it shows on the sensible level, that the individual soul can count and generate arithmeti$\mathrm{cal} /$ quantitative numbers in succession: it creates an external number which can sum together a man and a horse up, disregarding the essential characteristics that define both.

This presentation of the generation of arithmetical numbers is somehow similar to the 'Aristotelian' abstractionism as it was conceived by some of his commentators, in that it seems to attribute to the soul not only the power to make arithmetical unities - once the different qualities of beings have been 'forgotten'-identical one to each other in order to constitute the 'matter' of calculus, but also to generate them by the thought. But, unlike what the Aristotelian model seems to argue, such an abstraction produces a false science, since it considers the mathematical/quantitative characteristics common to all sensible beings as objects of calculus, thus ignoring both the substantial features that make a man completely different from a horse and the essential number that imprints a group of beings from the common and essential nature that is produced by the eidetic participation. Now, from a Platonic point

30 See the discussion of this thesis in C. Maggi (2009) 238-239 and cross references.

31 For the distinction between numbered numbers and numbering ones see E. Amado (1953).

32 PLOT. Vi 6, 16, 14-18 (ARmStrong's transl.). See also lines $20 \mathrm{ff.}$ 
of view, these numbers, once the eidetic participation has been completely removed from the attributes of a being, are per se nothing. ${ }^{33}$

\section{Iamblichus, and the Rethinking of Abstraction}

Iamblichus is the vehicle of a process that puts together the Platonic and the Pythagorean traditions, so to create the conditions for the description of the perfect philosopher, who was, according to him, Pythagoras, and to establish a metaphysical structure based upon the Platonic dualism between ideas and sensible entities, on the one hand, and on the Neopythagorean system of the One and the Dyad as principles of reality, on the other. Iamblichus therefore retains the Pythagorean idea of the role of mathematics as capable of turning the soul back to its principles. This is why he is more interested than Plotinus in the intermediate status of mathematical entities and in their being separate both from sensible beings and from the intelligible ones.

Here I will focus on some of these themes present in Iamblichus' De communi mathematica scientia and Introductio Arithmetica - belonging to the socalled Compendium to Pythagorean Doctrine, part of which, now lost, has been passed on by Psellus. ${ }^{34}$ Such themes are based in some way both on the reduction in the Academic sense, and on the abstraction in the Aristotelian one.

First of all, the relationship between the four parts of mathematical science-arithmetic, geometry, music and astronomy — has to be considered. They are related to each other by a principle that is quite similar to the Academic reduction/subtraction mentioned before. Choosing arithmetic as first, Iamblichus highlights that numbers owe their place to the fact that they are simpler than the object of other mathematical branches. This simplicity is not only epistemologically, but also ontologically structured, for the object

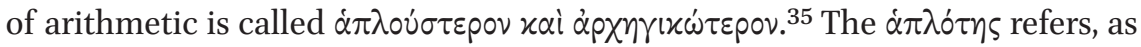
in Plotinus, to a nature capable of remaining in itself thanks to its turning to the One. Given that the degree of simplicity of a nature rests on its closeness to the first principle, numbers come ontologically first for they are much sim-

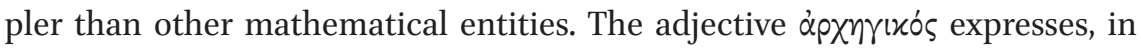
the Neoplatonic system, a cause that generates its effects while not possessing

33 See R. Chiaradonna (2002) 108-109; 278-28o. For the role of quantity see Ch. Horn (1995) $32 \mathrm{ff}$.

34 For the reconstruction of books 5-7 see D. J. O'Meara (1989) 217-229. For a presentation of the whole Compendium see B. Dalsgaard Larsen (1972) 44-45; L. M. Napolitano Valditara (1988) 540; 544; D. J. O'Meara (1989) 33-34; F. Romano (2006) 11-53; L. Brisson (2012) 37-38. 
in itself the features of the very effects it generates. ${ }^{36}$ It can be argued that arithmetic can exist without the other branches of science, while these need arithmetic to come into being.

Such a use of the reduction/causal model is effective to describe all levels of reality. In relation to the principles of the Limit and the Unlimited, which are common to any mathematical object and to ideas and sensible beings, Iamblichus says:

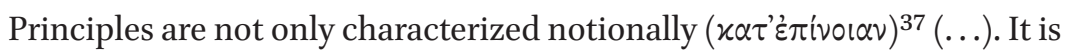
not the same thing for an immaterial entity to exist in itself and to make

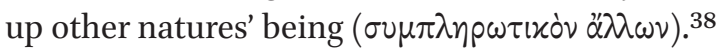

The term sं $\pi^{\prime}$ vol $\alpha$ occurs in Alexander, by whom it is used to indicate something existing only in our thought. Iamblichus, on the contrary, is establishing a parallel between the epistemological priority and the ontological one, by which what is prior as an object of our thought is also prior by nature, for the individual soul thinks according to a vertical structure corresponding to the structure of reality, the order of which follows the rule higher/lower, more simple/less simple and has as its principles the Limit and the Unlimited. A generative cause cannot be put at the level of the things that are generated. It is separate from them and by virtue of this separation, it is able to give existence to everything else. ${ }^{39}$

These notions also allow Iamblichus to borrow from Aristotle the ontological tripartition attributed to Plato, so that he may claim both the intermediate status of mathematical beings and their ontologically separate nature from ideas and sensible entities. ${ }^{40}$ First of all, he underlines the supremacy of the eidetic entities on the mathematical ones by virtue of the principle of simplicity:

36 See C. Maggi (2010) 167-171; 173-178. For the notion of cause see also S. Mesyats (2012) 151152 , where the problem is treated with respect to the status of the One in Neoplatonic tradition.

37 For the use of the term epinoia in Neoplatonic mathematical ontology after Plotinus see G. R. Giardina (2000) 158-159 and notes 28-29.

38 IAMBL. comm. math. sc. 49, 22-28.

39 See IAmBL. comm. math. sc. 50, $1 \mathrm{ff}$. Proclus himself will attribute to Iamblichus such a notion of cause. See PROCL. in tim. II 240, 4 ff. = IAMBL. in tim. fr. 54 and J. M. Dillon (1987) 890; J. M. Dillon (1993) 49-50; 53 note 6.

40 See IAM BL. comm. math. sc. 10, 7-13. For the differences between Iamblichus and Aristotle see C. Maggi (2010) 173-178. 
The <proper $>$ principles of mathematical beings differ from the principles generating the $<$ higher $>$ intelligible level, $(. .$.$) since the former prin-$ ciples are less perfect, pure and simple. ${ }^{41}$

When he speaks of the ontological tripartite model, Iamblichus seems to consider the ontological simplicity also as a way to distinguish the status of mathematical entities from that of sensible beings:

In general, about the mathematical objects, we must admit the following axioms $(\dot{\alpha} \xi i(\omega) \mu \tau \tau)$ : they are bodiless and able to exist in themselves, so that they are intermediate between what is absolutely indivisible and separate and what is linked to the sensible bodies (...) since they are simpler than the logo $i$ in the bodies but less purely separate than the ideas. ${ }^{42}$

Here we find an interesting intersection between the Aristotelian tripartition and the Plotinian intelligible structure of reality, since Iamblichus replaces the Aristotelian expression "sensible entities" with the notion of $\lambda$ orol (probably denoting, as in Plotinus, the presence of intelligible ideas, being separate in themselves, in the sensible realm), in order to suggest a quite different tripartite model according to which $\tau \dot{\alpha} \mu \alpha \theta \eta \mu \alpha \tau i x \dot{\alpha}$ are no longer intermediate between ideas and bodies: they are rather intermediate between the intelligible separate ideas and the intelligible immanent logoi.43

In addition, Iamblichus interprets the Aristotelian tripartition from a generative point of view by which everything lower is produced by the higher level, so that the former is the image of the latter:

The intelligible beings are double: the former are the objects of the <intelligible> science; the latter are related to the dianoetic thought. (...) Together with the object of noetic science and of dianoetic one there is

41 IAMBL. comm. math. sc. 50, 14-16.

42 IAMBL. comm. math. sc. 10, 7-13.

43 It follows that, whereas in the Aristotelian model mathematical entities differ from the sensible ones by their eternal and motionless nature, Iamblichus introduces the idea that there are three different ways for an intelligible nature to relate itself to the sensible one, that is, 1) the idea, which is completely separate; 2) the logos, which is the eidetic presence in sensible bodies; 3 ) and mathematical beings, which are related to the sensible realm from an epistemological point of view, since the individual soul needs to discover a mathematical order in the lower level so to bring itself to the eidetic level. See IAMBL. comm. math. sc. 10, 13 ff.; 50, 24; protr. 125, $1 \mathrm{ff}$; NICOM. intr. arith. I 3, 6. For the notion of logos in Plotinus see L. Brisson (1999); L. Brisson (2000). 
also another type of substance: we are speaking about the sensible entities, which are derived from those which we spoke about before. (...). Dianoetical entities (...) are like intelligible beings descending into a

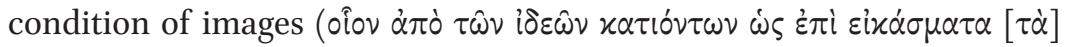

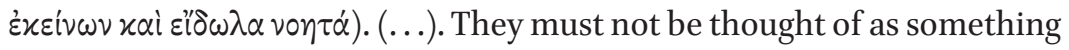
derived from the sensible level by an operation of abstraction, since

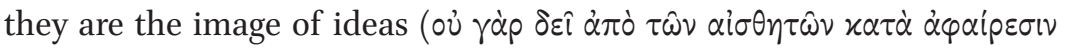

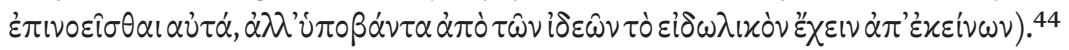

In the passage quoted above, Iamblichus refers to the Platonic divided line, and yet, what is more significant, he does not mention Plato, but a series of Neopythagorean texts considered by him as more ancient than Plato's himself. Moreover, whereas the Platonic divided line has a somewhat epistemological character, the Iamblichean one is rather ontological and vertically caused, for it postulates that mathematical entities are generated by the more highly structured forms. ${ }^{45}$

In such a direction the Aristotelian abstractionism is refused, so denying the dependence of mathematical entities on what is inferior, since it is not possible for what is higher to derive its reason from what is lower. ${ }^{46}$

Moreover, since, as we said, Iamblichus is more interested than Plotinus in mathematical sciences, he uses the causal action to recognize a specific mathematical method and admits, at the same time, that it can be extended to dialectics as well as to knowledge associated with the sensible realm. ${ }^{47}$

In the same direction Iamblichus reclaims the notion of intelligible matter, introduced by Aristotle within his model of abstraction. Once Aristotle, as mentioned, has refused the ontological separation of mathematical entities, he has to account for the fact that an individual geometrical object can be thought "in abstraction from the fact that it is composed, for example,

44 IAMBL. comm. math. sc. 32, 13 ff. and F. Romano (2000) 8-9.

45 See plat. resp. VI 509 D 6-511 E 5. For the difference between the Iamblichean account, influenced by the Neopythagorean texts of the imperial age, and the Platonic one see L. M. Napolitano Valditara (200o) 46; 49; 52; 64-69.

46 The Pseudo-Alexander (in metaph. 1077b $14 \mathrm{ff}$.) probably borrowed from Iamblichean criticism some notions: when he states that we must $[\tau \dot{\alpha} \mu \alpha \theta \eta \mu \alpha \tau i x \dot{\alpha}] \dot{\alpha} \pi \dot{o} \tau \hat{\omega} \nu \alpha i \sigma \theta \eta \tau \hat{\omega} \nu$

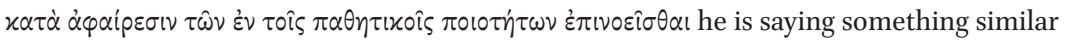
to what we find in Iamblichus; in this case, however, there is an inversion of Iamblichus' epistemology, in as much as the Pseudo-Alexander regards mathematical entities as derived from sensible entities by means of our thought. See C. Maggi (2010) 178-184.

See C. Maggi (2012) 82 . 
of bronze". ${ }^{48} \mathrm{He}$ resorts to the notion of matter as intelligible, conceived as what allows to imagine geometrical shapes and what makes it possible to think about the parts of a specific geometrical object, considered as a whole, as if they had properties which the whole does not possess. But, just as geometrical shapes are not really separated from sensible entities, for they result from a functional separation capable of establishing the object of mathematical science, in the same way the intelligible matter, acting as a substratum for these objects, does not exist by itself, but represents what makes it possible for the geometrical object to be thought qua bestowed with spatial configuration. ${ }^{49}$

Plotinus' resumption of this notion is partly similar to his rethinking of the Academic notion of Indefinite Dyad in order to underline the absolute supremacy of the One: the so-called intelligible matter is what makes forms multiple and therefore different from the Principle; but, at the same time-since it is devoid of multiplicity from itself-, it points to the similarity of multiplicity to the One from which multiple derives. ${ }^{50}$

Whereas Plotinus defends an absolute mono-polar framework, Iamblichus, though not refusing monism in a deeper sense, ${ }^{51}$ adopts the Pythagorean duplicity of archai, which Plato himself would borrow from Pythagoras when constructing the system of the gene of being, ${ }^{2}$ in order to exorcize "sensible matter of the evil with which it had been identified by Gnostics, Platonic dualists, and even by Plotinus. ${ }^{53}$ Once supposed the simplicity of the One-which is the resemblance pattern which makes beings similar to each other, so that they can be reduced to their common principle-, we must likewise accept the multiplication of kinds of matter or dyads - conceived as the principle of diversification, which makes the levels of reality multiple-, each one adequate to any level of reality and dependent directly on the highest intelligible matter, that is the aoristos duas. ${ }^{4}$ The presence of matter both in the ideal realm and in the sensible one is thus what makes possible to connect both of them to the mathematical level as intermediate.

\footnotetext{
48 J. Lear (1982) 182.

49 See C. Maggi (2012) 77-78.

$50 \quad$ See C. Maggi (2009) 74-78; C. Maggi (2010) $117 \mathrm{ff}$.

51 See G. Shaw (1995) 33; G. Shaw (1999) 129; G. Van Riel (1997) 44-45.

52 See IAMBl. in nic. 78, 18-19 and J. M. Dillon (1973) 268-270; 319-320; J. M. Dillon (1997) 71.

53 G. Shaw (1999) 129. For a whole interpretation of the relationship between evil and matter see, in particular, J.-M. Narbonne (2011) 11 ff.; 79 ff. See also J. M. Dillon (1987) 898899; J. Opsomer (2001); G. Van Riel (1997) 36-37; 42.

See IAMBL. comm. math. sc. 14, 9-10; 12-16; 17, 25-27; 28-29; C. Maggi (2012) 83-84; G. Shaw (1995) 29 .
} 
Another specific Iamblichean interest, which makes his model of mathematics and plurality quite different from the Plotinian one, is the effort to reach an agreement, thanks to the Pythagorean ontology, between the Platonic and Aristotelian traditions not only in metaphysics, but also in the mathematical model..$^{55}$ This effort becomes the condition for a reconsideration of the theory of abstraction. Even though Iamblichus rules out the role of abstraction, he nevertheless saves it in a Platonic framework, when, in his account of the Pythagorean range of application of mathematical sciences to sensible beings, he states that in such sciences shapes and figures are detached from the bodies

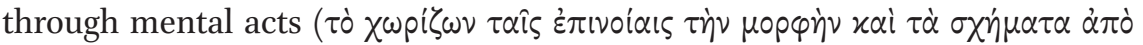
$\tau \hat{\omega} \nu \sigma \omega \mu \alpha \dot{\tau} \tau \omega \nu) .{ }^{56}$ However, it is a kind of abstraction which does not concern, like Aristotle claimed, functional abstraction: it is rather a 'Platonizing' abstraction, which concerns the power to separate immanent reasons and immanent

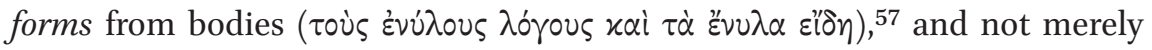
'Aristotelian' attributes, ${ }^{58}$ by virtue of the power of imagination, according to which any arithmetical or geometrical operation would be no more than the result of a projection produced by the soul from principles which are innately part of it and that somehow transcend it, so that imagination becomes the opposite of Aristotelian abstraction. ${ }^{59}$

Something similar may be found in Plotinus when he speaks of numbers connected to quantity and criticizes them. However, while Plotinus emphasizes the lower-higher generation of arithmetical numbers and excludes the existence of anything different from the higher structure represented by the eidetic numbers, Iamblichus, in defending their intermediate status, has to admit $a$ sort of abstraction conceived as the means which links the different lower levels of realms to the higher ones.

\section{References}

Amado, E. 1953. 'A propos des nombres nombrés et des nombres nombrants chez Plotin'. Revue Philosophique de la France et de l'étranger 78, 423-425.

Barnes, J. 1985. 'Aristotelian Arithmetic'. Revue de Philosophie Ancienne 3, 97-133.

55 See Ph. Hoffmann (1980) 309.

56 IAMBL. comm. math. sc. 64, 16-17.

57 IAMB L. comm. math. sc. 64, 13-14.

58 See C. Maggi (2012) 85-87.

59 See my discussion in C. Maggi (2012) 82 and cross references. 
Bechtle, G. 2011. Speusippus's Neutral Conception of the One and Plato's Parmenides, in J. D. Turner, K. Corrigan (edd.), Plato's Parmenides and Its Heritage. Volume 1: History and Interpretation from the Old Academy to Later Platonism and Gnosticism. LeidenBoston: Brill, 37-58.

Berti, E. 1997. La filosofia del 'primo' Aristotele. Milano: Vita e Pensiero.

Brisson, L. 1999. 'Lógos et lógoi chez Plotin. Leur nature et leur rôle'. Les Cahiers philosophiques de Strasbourg 8, 87-108.

-2000. Le logos chez Plotin, in N. L. Cordero (éd.), Ontologie et dialogue. Mélanges en hommage à P. Aubenque avec sa collaboration à l'occasion de son $70^{e}$ anniversaire. Paris: Vrin, 47-68.

2012. Chapter 18 of the De communi mathematica scientia. Translation and Commentary, in E. Afonasin, J. M. Dillon, J. Finamore (edd.), Iamblichus and the Foundations of Late Platonism. Leiden: Brill, 37-49.

Cattanei, E. 1996. Enti matematici e metafisica. Platone, l'Accademia e Aristotele a confronto. Milano: Vita e Pensiero.

- 2003. Gli enti matematici 'per astrazione' secondo Alessandro di Afrodisia e lo Pseudo-Alessandro, in G. Movia (ed.), Alessandro di Afrodisia e la Metafisica di Aristotele. Milano: Vita e Pensiero, 255-276.

Centrone, B. 2009. La testimonianza aristotelica sui principi pitagorici in Metaphysica Alpha. Un resoconto distorto?, in R. L. Cardullo (ed.), Il libro Alpha della Metafisica di Aristotele tra storiografia e teoria. Atti del Convegno nazionale (Catania 16-18 gennaio 2008). Catania: CUECM, 21-36.

Chiaradonna, R. 2002. Sostanza movimento analogia. Plotino critico di Aristotele. Napoli: Bibliopolis.

- 2010. Sostanze intelligibili e unità numerica in Plotino, in D. P. Taormina, D. J. O'Meara, Ch. Riedweg (edd.), L'essere del pensiero. Saggi sulla filosofia di Plotino. Napoli: Bibliopolis, 123-135.

Cleary, J. J. 1995. Aristotle and Mathematics. Aporetic Method in Cosmology and Metaphysics. Leiden-New York-Köln: Brill.

Dalsgaard Larsen, B. 1972. Jamblique de Chalcis. Exégète et philosophe. Aarhus: Universitatsforlaget.

Dillon, J. M. (ed.) 1973. Iamblichi Chalcidensis in Platonis dialogos Commentariorum Fragmenta. Leiden: Brill.

— 1987. 'Iamblichus of Chalcis'. Aufstieg und Niedergang der Römischen Welt 36.2, 862-909.

- 1993. Iamblichus and Henads Again, in H. J. Blumenthal, E. G. Clark (edd.), The divine Iamblichus. Philosopher and Man of Gods. London: Bristol Classical Press, 48-54.

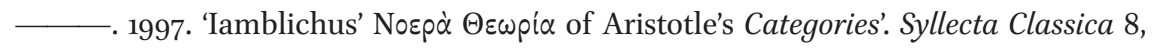
65-77. 
Fine, G. 1993. On Ideas. Aristotle's Criticism of Plato's Theory of Forms, Oxford: Clarendon Press.

Flannery, K. L. 2003. Mathematical Entities in Alexander and Pseudo-Alexander of Aphrodisias, in V. Celluprica (ed.), Il libro B della Metafisica di Aristotele. Atti del Colloquio (Roma, 30 nov.-1 dic. 200o). Napoli: Bibliopolis, 127-157.

Giardina, G. R. 2000. Il concetto di numero nell'in Nicomachum di Giovanni Filopono, in G. Bechtle, D. J. O'Meara (éds.), La philosophie des mathématiques de l'Antiquité tardive. Actes du colloque international (24-26 septembre 1998). Fribourg Suisse: Éditions Universitaires Fribourg Suisse, 149-171.

Hoffmann, Ph. 1980. 'Jamblique exégète du pythagoricien Archytas: trois originalités d'une doctrine du temps'. Les Études Philosophiques 3, 307-323.

Horn, Ch. 1995. Plotin über Sein, Zahl und Einheit. Eine Studie zu den systematischen Grundlagen der Enneaden. Stuttgart-Leipzig: Teubner.

Kalligas, P. 2011. 'The structure of appearances: Plotinus on the constitution of sensible objects'. The Philosophical Quarterly 61, 762-782.

Lear, J. 1982. 'Aristotle's Philosophy of Mathematics'. The Philosophical Review 91, 161-192.

Maggi, C. (ed.) 2009. Plotino. Sui numeri. Enneade vт 6 [34]. Introduzione, testo, traduzione e commento. Napoli: Università degli Studi Suor Orsola Benincasa.

- 2010. Sinfonia matematica. Aporie e soluzioni in Platone, Aristotele, Plotino, Giamblico. Napoli: Loffredo.

- 2012. Iamblichus on mathematical entities, in E. Afonasin, J. M. Dillon, J. Finamore (edd.), Iamblichus and the Foundations of Late Platonism. Leiden: Brill, $75^{-89}$.

Mesyats, S. 2012. Iamblichus' Exegesis of the Parmenides' Hypotheses and His Doctrine of Divine Henads, in E. Afonasin, J. M. Dillon, J. Finamore (edd.), Iamblichus and the Foundations of Late Platonism. Leiden: Brill, 151-175.

Mignucci, M. 1987. Aristotle's Arithmetic, in A. Graeser (ed.), Mathematics and Metaphysics in Aristotle. Mathematik und Metaphysik bei Aristoteles. Akten des X. Symposium Aristotelicum (Sigriswil, 6-12 September 1984). Bern-Stuttgart: Paul Haupt Berne, 175-211.

Mueller, I. 1990. Aristotle's Doctrine of Abstraction in the Commentators, in R. Sorabji (ed.), Aristotle Transformed. The Ancient Commentators and their Influence. London: G. Duckworth \& Co. Ltd., 463-480.

Napolitano Valditara, L. M. 1988. Le idee, i numeri, l'ordine. La dottrina della mathesis universalis dall'Accademia antica al neoplatonismo. Napoli: Bibliopolis.

- 2000. Giamblico e la linea divisa (comm. sc. 32, 8-40, 6 Festa), in G. Bechtle, D. J. O'Meara (éds.), La philosophie des mathématiques de l'Antiquité tardive. Actes $\mathrm{du}$ colloque international (24-26 septembre 1998). Fribourg Suisse: Éditions Universitaires Fribourg Suisse, 45-69.

Narbonne, J.-M. 2011. Plotinus in Dialogue with the Gnostics. Leiden-Boston: Brill. 
Ninci, M. (ed.) 200o. Plotino. Il pensiero come diverso dall'uno. Quinta enneade. Introduzione, traduzione e commento. Milano: Rizzoli.

- 2001. 'Un problema plotiniano: l'identità con l'uno e l'alterità da lui'. Giornale Critico della Filosofia Italiana 80, 461-506.

- 2010. La cosa e il suo perché. Intelligibile e sensibile in Plotino, in D. P. Taormina, D. J. O'Meara, Ch. Riedweg (edd.), L'essere del pensiero. Saggi sulla filosofia di Plotino. Napoli: Bibliopolis, 139-212.

O'Meara, D. J. 1989. Pythagoras Revived. Mathematics and Philosophy in Late Antiquity. Oxford: Clarendon Press.

Opsomer, J. 2001. 'Proclus vs Plotinus on Matter (De mal. subs. 30-7)'. Phronesis 46, 154-188.

Repellini, F. F. 2003. La linea e la caverna, in M. Vegetti (ed.), Platone. La Repubblica V. Napoli: Bibliopolis, 355-403.

Robertson, D. G. 2004. 'Chrysippus on Mathematical Objects'. Ancient Philosophy 24, 169-191.

Romano, F. 2000. Le rôle de la mathématique dans le projet d'unification des sciences chez Jamblique, in G. Bechtle, D. J. O'Meara (éds.), La philosophie des mathématiques de l'Antiquité tardive. Actes du colloque international (24-26 septembre 1998). Fribourg Suisse: Éditions Universitaires Fribourg Suisse, 1-13.

— ( ed.) 2006. Giamblico. Summa Pitagorica. Introduzione, traduzione, note e apparati. Milano: Bompiani.

Shaw, G. 1995. Theurgy and the Soul. The Neoplatonism of Iamblichus. University Park (PA): The Pennsylvania State University Press.

- 1999. 'Eros and Arithmos: Pythagorean Theurgy in Iamblichus and Plotinus'. Ancient Philosophy 19, 121-143.

Slaveva-Griffin, S. 2009. Plotinus on Number, Oxford-New York: Oxford University Press. Szlezák, Th. A. 2008. Le témoignage d'Aristote, in J. L. Périllié (éd.), Platon et les Pythagoriciens. Hiérarchie des savoirs et des pratiques. Musique-Science-Politique. Bruxelles: Ousia, 93-115.

- 2011. The Indefinite Dyad in Sextus Empiricus's Report (Adversus Mathematicos 10.248-283) and Plato's Parmenides, in J. D. Turner, K. Corrigan (edd.), Plato's Parmenides and Its Heritage. Volume 1: History and Interpretation from the Old Academy to Later Platonism and Gnosticism. Leiden-Boston: Brill, 79-91.

Van Riel, G. 1997. 'The Transcendent Cause: Iamblichus and the Philebus of Plato'. Syllecta Classica 8, 31-46. 